\title{
Contributions of secondary forest and nitrogen dynamics to terrestrial carbon uptake
}

\author{
X. Yang, T. K. Richardson, and A. K. Jain \\ Department of Atmospheric Sciences, University of Illinois, Urbana, IL 61801, USA
}

Received: 24 January 2010 - Published in Biogeosciences Discuss.: 14 April 2010

Revised: 15 August 2010 - Accepted: 3 September 2010 - Published: 8 October 2010

\begin{abstract}
We use a terrestrial carbon-nitrogen cycle component of the Integrated Science Assessment Model (ISAM) to investigate the impacts of nitrogen dynamics on regrowing secondary forests over the 20th century. We further examine what the impacts of nitrogen deposition and land use change history are on terrestrial carbon uptake since preindustrial time. Our results suggest that global total net land use emissions for the 1990s associated with changes in cropland, pastureland, and wood harvest are $1.22 \mathrm{GtC} / \mathrm{yr}$. Without considering the secondary forest regrowth, the estimated net global total land use emissions are $1.58 \mathrm{GtC} / \mathrm{yr}$ or about $0.36 \mathrm{GtC} / \mathrm{yr}$ higher than if secondary forest regrowth is considered. Results also show that without considering the nitrogen dynamics and deposition, the estimated global total secondary forest sink for the $1990 \mathrm{~s}$ is $0.90 \mathrm{GtC} / \mathrm{yr}$ or about $0.54 \mathrm{GtC} / \mathrm{yr}$ higher than estimates that include the impacts of nitrogen dynamics and deposition. Nitrogen deposition alone is responsible for about $0.13 \mathrm{GtC} / \mathrm{yr}$ of the total secondary forest sink. While nitrogen is not a limiting nutrient in the intact primary forests in tropical regions, our study suggests that nitrogen becomes a limiting nutrient for regrowing secondary forests of the tropical regions, in particular Latin America and Tropical Africa. This is because land use change activities, especially wood harvest, removes large amounts of nitrogen from the system when slash is burnt or wood is removed for harvest. However, our model results show that carbon uptake is enhanced in the tropical secondary forests of the Indian region. We argue that this may be due to enhanced nitrogen mineralization and increased nitrogen availability following land use change in the Indian tropical forest ecosystems. Results also demonstrate that there is a significant amount of carbon accumulating in the Northern Hemisphere where most land use changes and forest regrowth has
\end{abstract}

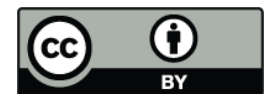

Correspondence to: A. K. Jain (jain1@uiuc.edu) occurred in recent decades. This study indicates the significance of secondary forests to terrestrial carbon sinks, the importance of nitrogen dynamics to the magnitude of secondary forests carbon uptake, and therefore the need to include both primary and secondary forests and nitrogen dynamics in terrestrial ecosystem models.

\section{Introduction}

Human activities have significantly altered the Earth's vegetation cover in nearly every part of the world. Such changes have the potential to alter regional and global climate through changes in the biophysical characteristics of the Earth's surface, such as albedo and surface roughness and in the biogeochemical cycles of terrestrial ecosystems, such as the global carbon $(\mathrm{C})$ and nitrogen $(\mathrm{N})$ cycles. Historically, land use change (LUC), such as the conversion of forests to croplands and pasturelands, has generally released $\mathrm{C}$ to the atmosphere due to the burning of forest biomass and subsequent decomposition of the dead organic matter. However in recent decades, C stocks in forest ecosystems have increased through reforestation, afforestation and forest regrowth on abandoned land (Houghton et al., 1999). Recent studies suggest that forest regrowth is one of the important causes of the net carbon sink in terrestrial biosphere over the past few decades (Canadell et al., 2007; Houghton et al., 2005; Denman et al., 2007). Caspersen et al. (2000) shows that carbon sinks in forests in the US are caused largely by forest recovery from prior LUC, accounting for more than $90 \%$ of the carbon sink in the US Houghton et al. (1999) estimate C sink of about $0.35 \mathrm{GtC} / \mathrm{yr}$ due to forest regrowth in the $1980 \mathrm{~s}$ in the United States. Shevilakova et al. (2009) show that, on a global scale, secondary forests were a substantial sink of $\mathrm{C}$ during the $1990 \mathrm{~s}$, accumulating $0.35-0.6 \mathrm{GtC} / \mathrm{yr}$.

However, as our previous study also suggest that the accumulation of $\mathrm{C}$ in regrowing forests can be constrained if

Published by Copernicus Publications on behalf of the European Geosciences Union. 
the regrowth of forest occurs in $\mathrm{N}$ limited regions (Jain et al., 2009) or enhanced if the additional $\mathrm{N}$ is deposited in the forest regrowing regions (Jain et al., 2009). While Jain et al. (2009) did not consider the LUC changes for wood harvest, pasturelands and the associated secondary forests; our model results demonstrated that the impact of $\mathrm{N}$ limitation on terrestrial net C flux during the 1990s is spatially heterogeneous across the globe. In general, the inclusion of $\mathrm{N}$ dynamics significantly reduces the $\mathrm{CO}_{2}$ fertilization response relative to the case where $\mathrm{N}$ is sufficiently available for plants to grow, in particular in moist temperate regions where $\mathrm{N}$ is a primary limiting nutrient. While high latitude boreal forests and tundra regions are also limited in $\mathrm{N}$ availability, the response of these regions to $\mathrm{N}$ limitation is less pronounced than the temperate evergreen deciduous and evergreen forest regions because ecosystem productivity in high latitudes is limited by shorter growing seasons and relatively less $\mathrm{N}$ is required for plant growth. While tropical regions are highly productive, our previous study (Jain et al., 2009) results indicate that $\mathrm{N}$ does not limit productivity in tropical primary forests.

$\mathrm{N}$ is a primary limiting nutrient in mid- and high-latitude regions (Vitousek and Howarth, 1991). In tropical regions, $\mathrm{N}$ is usually not considered as a limiting nutrient because the warmer and wetter tropical climate enhances $\mathrm{N}$ mineralization in soils (Vitousek and Howarth, 1991) and biological N fixation is high. The exception is in montane tropical forests, where $\mathrm{N}$ mineralization is greatly reduced due to temperature and moisture constraints (Tanner et al., 1998). However, studies suggest that $\mathrm{N}$ is an important limiting nutrient in secondary forest in tropical lowland regions (Davidson et al., 2004; Herbert et al., 2003). This is supported by a recent meta-analysis of 126 number of studies, where $\mathrm{N}$ limitation is shown clearly for tropical secondary forest in a magnitude similar to that identified for temperate forests, whereas there was no indication of $\mathrm{N}$ limitation in the primary tropical forest sites (Lebauer and Treseder, 2008).

LUC history can also impact the $\mathrm{N}$ status of soils. $\mathrm{N}$ is lost from soils after the clearing of forests for cropland and/or pastureland due to leaching, erosion and higher decomposition rates (Herbert, 2003; Mathers et al., 2006). A large fraction of biomass $\mathrm{N}$ is volatilized during clearing and burning of forest (Davidson et al., 2004). N is also lost through enhanced leaching due to soil erosion (Pimentel and Kounang, 1998.). Furthermore, cultivation also removed ecosystem N due to crop consumption and export. Schipper et al. (2007) indicates that significant amount of soil $\mathrm{C}$ and $\mathrm{N}$ is lost from soils under pasture in New Zealand during 20 years time period. Therefore it is expected that regrowing forest would very likely be nitrogen limited.

On the other hand, $\mathrm{N}$ deposition on terrestrial ecosystems has increased continuously due to human activity through crop production and energy production (Galloway et al., 2004), especially beginning with the green revolution when the Haber process became widely used to provide fertilizer for expanding crop production (Smil, 2001). The combustion of fossil fuels and the use of $\mathrm{N}$ fertilizer in agriculture have released significant amounts of reactive $\mathrm{N}$ in the form of nitric oxide (NO), nitrous oxide $\left(\mathrm{NO}_{2}\right)$ and ammonia $\left(\mathrm{NH}_{3}\right)$, into the atmosphere over the last century. In 2000, global emissions of $\mathrm{NO}$ and $\mathrm{NH}_{3}$ are 52.1 and $64.6 \mathrm{TgN} / \mathrm{yr}$ (Galloway et al., 2004). These reactive forms of $\mathrm{N}$ are converted to a number of other oxides of $\mathrm{N}\left(\mathrm{NO}_{\mathrm{y}}\right)$ as well as $\mathrm{NH}_{\mathrm{x}}$ and then deposited on land and ocean, with $50-70 \%$ of $\mathrm{NO}_{\mathrm{y}}$ and $60 \%$ of $\mathrm{NH}_{\mathrm{x}}$ to be deposited on terrestrial ecosystems (Reay et al., 2008). In systems that are $\mathrm{N}$ limited, such as temperate and boreal forests, the increased $\mathrm{N}$ deposition could alleviate or even remove $\mathrm{N}$ limitation on $\mathrm{C}$ uptake and lead to increased $\mathrm{C}$ sequestration. The key uncertainty is how much $\mathrm{C}$ could be sequestered in vegetation and soil due to $\mathrm{N}$ deposition and how long this stimulation effect would be sustained. Using a simplified ecosystem model, Townsend et al. (1996) estimated additional $\mathrm{C}$ uptake due to $\mathrm{N}$ deposition at a rate of $0.3-1.3 \mathrm{Gt} \mathrm{C} \mathrm{yr}^{-1}$ globally. In contrast, Holland et al. (1997) reported a global $\mathrm{C}$ sequestration rate of $1.5-2.0 \mathrm{GtC} \mathrm{yr}^{-1}$ using updated $\mathrm{N}$ deposition data. Nadelhoffer et al. (1999), however, showed that increased $\mathrm{N}$ deposition made a minor contribution in $\mathrm{C}$ sequestration in terrestrial ecosystems, arguing that most of deposited $\mathrm{N}$ ends up in soil that has lower $\mathrm{C}: \mathrm{N}$ ratio. These studies have not however considered the interactions between $\mathrm{N}$ deposition and other processes such as increasing atmospheric $\mathrm{CO}_{2}$ concentration $\left(\left[\mathrm{CO}_{2}\right]\right)$, climate change and LUC.

There are few studies in the literature which evaluate the interactive effects of $\mathrm{N}$ deposition and LUC at the global scale. Churkina et al. (2007) show that $\mathrm{N}$ deposition does not lead to significant $C$ sink unless it occurs with the regrowth of forest. Jain et al. (2009) examined the combined effect of increasing $\left[\mathrm{CO}_{2}\right]$, climate change, $\mathrm{N}$ deposition and LUC and show that forest regrowth in temperate regions is limited by $\mathrm{N}$ availability. While Churkina et al. (2007) assume constant LUC, Jain et al. (2009) consider LUCs for cropland and cropland abandonment and no LUC for pastureland and wood harvest. In addition, Jain et al. (2009) also assume that there are minimal $\mathrm{N}$ limitation effects in primary tropical forest and secondary tropical forests.

While the $\mathrm{C}$ sinks associated with regrowth of forest are commonly simulated within terrestrial $\mathrm{C}$ cycle models, the impacts of $\mathrm{N}$ limitations and $\mathrm{N}$ deposition on the $\mathrm{C}$ sink associated with regrowing forests have not been considered. The objectives of this study are to use the Integrated Science Assessment Model (ISAM), which couples the terrestrial C and $\mathrm{N}$ cycles for global change assessments, to examine the nitrogen limitation in secondary forests from historical LUC and the interactions between LUC and $\mathrm{N}$ deposition. 


\section{Methods}

\subsection{Model description}

The Integrated Science Assessment Model's carbon-nitrogen cycle model (ISAM-NC), is used to assess the impacts of LUC on terrestrial C uptake. ISAM-NC consists of fully prognostic $\mathrm{N}$ and $\mathrm{C}$ dynamics associated with LUC and changes in vegetation, above- and below-ground litter decomposition, and soil organic matter. ISAM-NC simulates C and $\mathrm{N}$ fluxes to and from different "compartments" of the terrestrial biosphere with 0.5-by-0.5 degree spatial resolution. The compartments consist of above and below-ground plant and soil pools. The $\mathrm{C}$ cycle includes feedback processes such as $\mathrm{CO}_{2}$ fertilization, climate (i.e. temperature and precipitation) effects on photosynthesis and respiration and increased $\mathrm{C}$ fixation by $\mathrm{N}$ deposition. The $\mathrm{N}$ cycle includes all the major processes including nitrogen fixation, immobilization, mineralization, nitrification, denitrification, leaching (Yang et al., 2009). In addition, model accounts for both symbiotic biological nitrogen fixation (BNF) and non-symbiotic BNF. We incorporated the empirical function developed by Schimel et al. (1996) to estimate BNF based on evaportranspiration (ET). We modified the parameters in the function in such a way so that the estimated BNF for each biome type is consistent with that given by Cleveland et al. (1999), which based on the field measurements and included both symbiotic BNF and non-symbiotic BNF (Yang et al., 2009). The structure, parameterization, and performance of the ISAMNC have been previously described in detail (Jain and Yang, 2005; Yang et al., 2009; Jain et al., 2009). In addition, ISAM$\mathrm{NC}$ has been extensively calibrated and evaluated using field measurements (Yang et al., 2009). The uncertainty in the model parameters and their impacts on the model results have also been investigated (Yang et al., 2009).

Originally, ISAM-NC accounted for 13 different land cover types. For the current study, five additional land cover types were added to represent secondary forest due to abandonment of cropland, pastureland, and wood harvest. These include: (1) secondary tropical evergreen forest, (2) secondary tropical deciduous forest, (3) secondary temperate evergreen forest, (4) secondary temperate deciduous forest, and (5) secondary boreal forest. The surface area of secondary forests varies with time in order to capture the historical legacy of abandonment of cropland, pasture land and wood harvest. The vegetation $\mathrm{C}$ and $\mathrm{N}$ dynamics of secondary forests were set to follow that of respective primary forests based on the assumption that forest will grow back if there is abandonment of cropland and pasture land or wood harvest. This assumption is based on the ecological phenomenon, secondary succession that starts with a disturbance such as forest fire or harvesting, progresses through initial colonization, canopy closure, recovery of species richness, increases in biomass, and ends with a return to the state similar to old-growth conditions (Horn, 1974; Guariguata and Ostertag, 2001). This assumption has also been implemented in previous modeling studies (Ramankutty et al., 2007; Woodbury et al., 2006). Dominant plant functional types could change through time during secondary succession (Guariguata and Ostertag, 2001). However in this study, we assume stationary land cover types of secondary forests for simplification.

The land use emissions of carbon due to LUC activities are calculated using the methods described in detail by Jain and Yang (2005). In brief, upon removal of natural vegetation in an affected land area, i.e. model grid cell, a specified fraction of vegetation biomass is transferred to litter reservoirs, effectively representing plant material left on the ground following deforestation activities. Some of the $\mathrm{C}$ and $\mathrm{N}$ in these reservoirs are subject to decomposition as discussed in Yang et al. (2009). The rest of plant material is either burned to clear the land for agriculture, which releases $\mathrm{C}$ (in the form of $\mathrm{CO}_{2}$ ) and $\mathrm{N}$ (either as $\mathrm{N}$ gases or mineral form of $\mathrm{N}$ ) contained in the burned plant material, or is transferred as $\mathrm{C}$ and $\mathrm{N}$ to wood and/or fuel product reservoirs. Carbon and $\mathrm{N}$ stored in the wood and/or fuel product reservoirs are released to the atmosphere at three rates dependent on the assigned product categories. Agriculture and agricultural products have turnover times of 1 year, paper and paper products have turnover times of 10 years, and lumber and long lived products such as furniture have turnover times of 100 years (Jain and Yang, 2005).

A separate version of ISAM which considers $\mathrm{C}$ cycle dynamics alone, ISAM-C, is used to compare the impact of excluding $\mathrm{N}$ cycle dynamics from assessments of LUC in a globally changing environment. ISAM-C has a $\mathrm{C}$ cycle component identical to the ISAM-NC but $\mathrm{N}$ availability is always in sufficient supply. The ISAM-C model has been used to investigate uncertainties in the land use emissions and net landatmosphere fluxes by using various different land use change datasets (Jain and Yang, 2005).

\subsection{Data}

\subsubsection{Land use change}

Over the period 1765-2000, we calculated historical net terrestrial C fluxes due to LUC based on the Hurtt et al. (2006) data that provide two land use history reconstructions. The first is based on the detailed land use history reconstruction of the HYDE dataset, which includes both cropland and pastureland reconstruction (Klein Goldewijk, 2001), and the other based on SAGE cropland reconstruction (Ramankutty and Foley, 1999) and HYDE pastureland reconstruction. Both land use reconstructions were supplemented with the FAO-based wood harvest reconstruction (FAOSTAT, 2004). There were more spatial details in the SAGE/HYDE reconstruction (Hurtt et al., 2006), and therefore the LUC reconstructions based on SAGE/HYDE are used here. The LUC activity related to shifting cultivation is not considered in this 


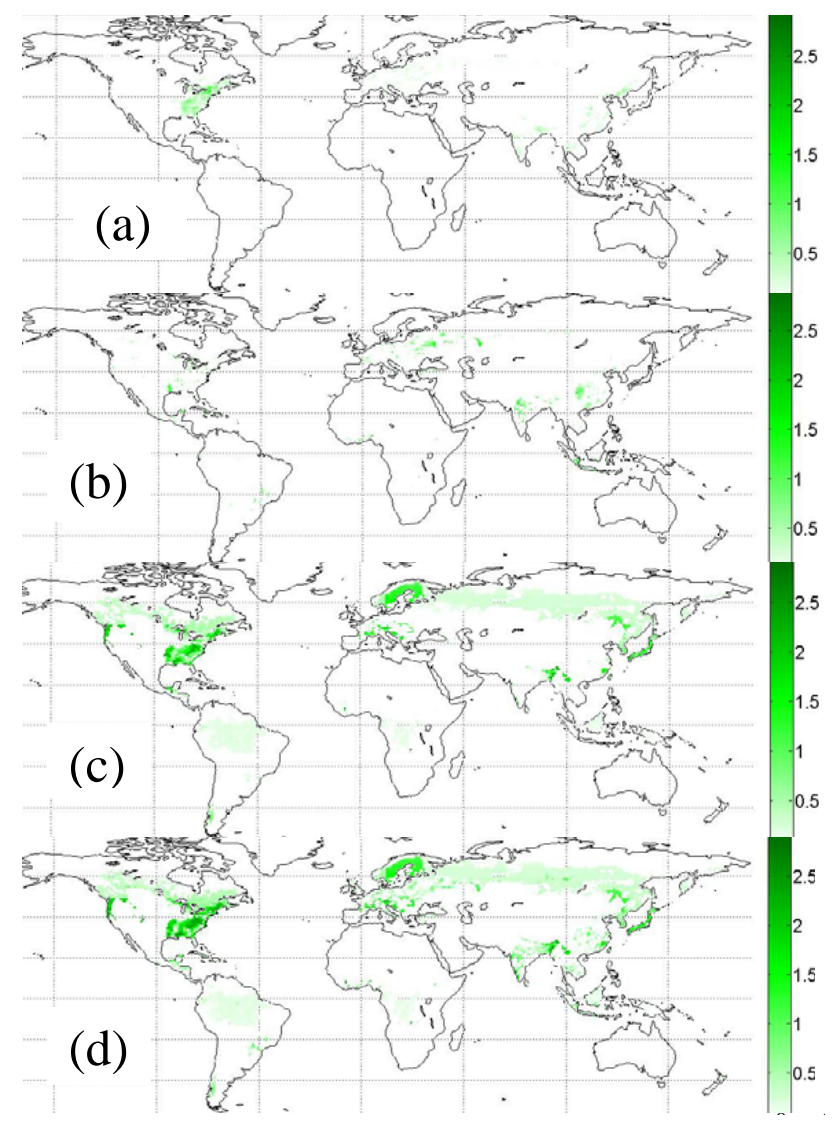

Fig. 1. The distribution of secondary forest area $\left(10^{9} \mathrm{~m}^{2}\right)$ regrown from (a) cropland abandonment, (b) pastureland abandonment, (c) wood harvest, and (d) sum of (a), (b) and (c).

study, because of large uncertainty associated with the shifting cultivation rate.

The area of secondary forests due to abandonment of cropland and pastureland and wood harvest increases from zero in 1765 to 7.42 million $\mathrm{km}^{2}$ in 1900 and 8.19 million $\mathrm{km}^{2}$ in 2000 (Fig. 1d). Area previously used for wood harvest is the largest contributor for an increase in secondary forest area, while abandonment of pastureland is the smallest contributor (Fig. 1). Most of the secondary forest regrowth occurs in North American and Eurasia regions. There is also an area of secondary forest in India and Eastern China. A small area of secondary tropical forest also exists in Latin America and tropical Africa due to regrowth of forest after wood harvest (Fig. 1c).

\subsubsection{Nitrogen deposition}

In ISAM-NC, the deposited amount of $\mathrm{N}\left(\mathrm{NO}_{\mathrm{y}}-\mathrm{N}\right.$ and $\mathrm{NH}_{\mathrm{x}}-$ $\mathrm{N}$ ) enters into ammonium-N pool and nitrate- $\mathrm{N}$ pool respectively (Yang et al., 2009). The deposited $\mathrm{N}$ could enter into the system either in the form of dry deposition or wet deposition, but this study does not make a distinction between
Table 1. Experiments performed for the period 1765-2000 for ISAM-NC and ISAM-C. The change of climate and atmospheric $\mathrm{CO}_{2}$ concentrations are considered in all experiments.

\begin{tabular}{lccc}
\hline Experiment & \multicolumn{2}{c}{ Land use change } & N deposition \\
& $\begin{array}{c}\text { Clearing of } \\
\text { natural vegetation }\end{array}$ & $\begin{array}{c}\text { Secondary } \\
\text { forest }\end{array}$ & \\
\hline ISAM-NC S1 & Yes & Yes & Yes \\
ISAM-NC S2 & No & No & Yes \\
ISAM-NC S3 & Yes & No & Yes \\
ISAM-NC S4 & Yes & No & No \\
ISAM-NC S5 & Yes & Yes & No \\
ISAM-C S6 & Yes & Yes & - \\
ISAM-C S7 & Yes & No & - \\
\hline
\end{tabular}

these two types of deposition. Changes in $\mathrm{N}$ deposition $\left(\mathrm{NO}_{\mathrm{y}}+\mathrm{NH}_{\mathrm{x}}\right)$ are based on Galloway et al. (2004), which account for both direct wet and dry depositions that result from recorded fertilizer application to agricultural land and incomplete combustion when fossil fuels are burned. and are calculated on a $5 \times 3.75^{\circ}$ grid using a global transport-chemistry model (Lelieveld and Dentener, 2000). Each grid data was then subdivided into a $0.5 \times 0.5$ sub-grid scale. Over the time period 1860-2000, the global total net exchange of $\mathrm{N}$ deposition flux from the atmosphere to land increases from 10.81 $\left(\mathrm{NO}_{\mathrm{y}}=6.45, \mathrm{NH}_{\mathrm{x}}=4.35\right)$ to $62.29\left(\mathrm{NO}_{\mathrm{y}}=26.1, \mathrm{NH}_{\mathrm{x}}=36.1\right)$ $\mathrm{TgN} / \mathrm{yr}$. For the period 1765-1859, we assume the $\mathrm{N}$ deposition was the same value as for 1860 .

\subsubsection{Climate and atmospheric $\mathrm{CO}_{2}$ concentrations}

The monthly temperature and precipitation data used in this study are the CRU TS 2.0 observation data set of the Tydall Center (Mitchell et al., 2005). These climate data are available for the period 1900-2000, and the resolution of this data set is 0.5 degrees. For grid cells with missing data sets, particularly in the early twentieth century, relaxation to the climatological data is applied to ensure the completeness of the data set in space and time. For initialization of ISAM between 1765 and 1899, the climate data is generated by randomly selecting yearly climate data between the period 1900 and 1920. Estimates of $\left[\mathrm{CO}_{2}\right]$ from ice cores (Neftel et al., 1985; Friedli et al., 1986) and direct measurements given by Keeling et al. (1982) are specified from 1765 through 1958. The average of annual $\left[\mathrm{CO}_{2}\right]$ from the Mauna Loa (Hawaii) and South Pole Observatories (Keeling and Whorf, 2007) is specified for the period from 1959 through 2000.

\subsection{Model experiments}

The ISAM is initialized with an $\left[\mathrm{CO}_{2}\right]$ of $278 \mathrm{ppmv}$, representative of approximate conditions in 1765 , and constant monthly mean temperature and precipitation for the period 1900-1920 (Mitchell et al., 2005) to allow vegetation and 


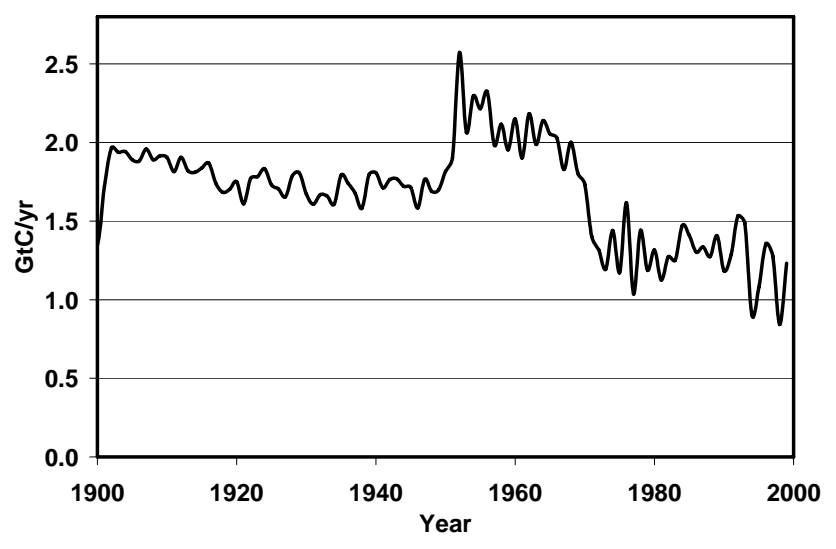

Fig. 2. ISAM estimated annual global mean emissions from land use change (GtC/year) for the period 1900-2000.

soil $\mathrm{C}$ and mineral $\mathrm{N}$ pools to reach an initial dynamic steady state (Yang et al., 2009). Once the model reaches dynamic steady state, seven transient experiments S1-S7 (Table 1) are performed to evaluate the contributions of LUC, secondary forests and $\mathrm{N}$ dynamics to terrestrial $\mathrm{C}$ fluxes on a global scale. Two versions of ISAM are used, ISAM-NC and ISAM-C, in order to compare the difference between model calculations that consider the interactions between the $\mathrm{C}$ and $\mathrm{N}$ cycle (ISAM-NC) and those that do not (ISAM-C). In the experiments where $\mathrm{N}$ deposition is not considered, we assume constant deposition level fixed at the 1765 level between 1765 and 2000.

\section{Results}

\subsection{Land use change emissions}

The land use emissions associated with changes in cropland, pastureland, and wood harvest are calculated by subtracting $\mathrm{C}$ fluxes based on experiment $\mathrm{S} 2$ from $\mathrm{C}$ fluxes based on experiment S1 (Table 1). Carbon emissions ( $\mathrm{GtC} / \mathrm{yr})$ due to LUCs reach a maximum in the early 1950 s declining thereafter (Fig. 2). The decrease in emissions is because the rate that natural vegetation was cleared for agriculture slowed and forest was regrowing across large areas on the east coast of the U.S. and Europe following the abandonment of agricultural land. Total global land use emissions for the 1990s are estimated by ISAM to be $1.22 \mathrm{GtC} / \mathrm{yr}$, which falls within the range of values estimated by IPCC AR4 $(0.5-2.7 \mathrm{GtC} / \mathrm{yr}$, median value of $1.6 \mathrm{GtC} / \mathrm{yr})$. Our estimate is also close to land use emissions given by Van Minnen et al. (2009) (1.3 GtC/yr in 1990s), in which HYDE data for cropland, pastureland and FAO wood harvest data were used.

The distribution of C sinks and sources in the 1990s due to LUC is shown in Fig. 3. There is a net release of $\mathrm{C}$ from terrestrial ecosystems in Amazonia, Southeast Asia, Latin America, and boreal region of North America and Eurasia

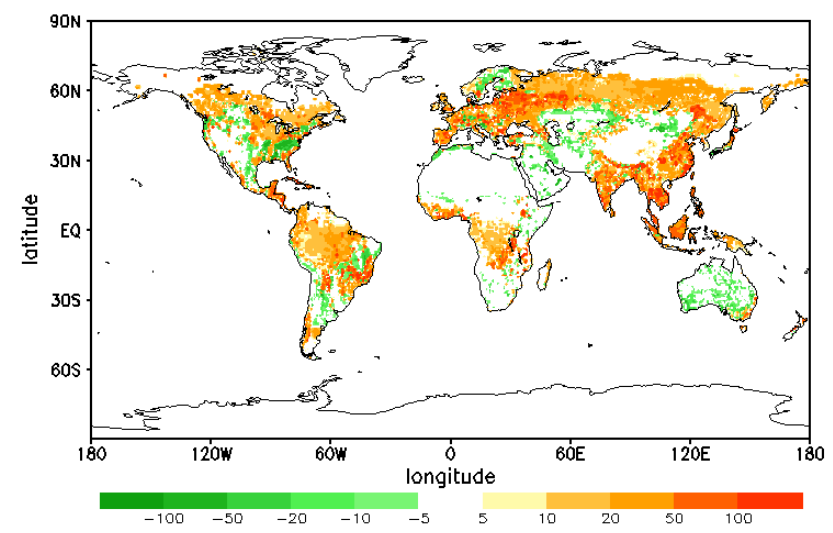

Fig. 3. ISAM estimated spatial distributions of carbon emissions from land use change in the 1990s (Unit: $\mathrm{gC} / \mathrm{m}^{2} / \mathrm{yr}$ ). Positive values represent net $\mathrm{C}$ release to the atmosphere and negative values represent net $\mathrm{C}$ storage in the terrestrial biosphere.

because the natural vegetation has been cleared for cropland, pastureland, wood harvest, which causes forest fire, the decomposition of agriculture, paper and wood products. Substantial regrowth of forest due to abandonment of agriculture land and wood harvest have contributed to the $\mathrm{C}$ sinks in Eastern United States, Europe, and Eastern China.

\subsection{The contribution of secondary forest to terrestrial carbon sinks}

To estimate the carbon fluxes in secondary forests we ran a third experiment (S3) with ISAM-NC. In S3, C fluxes in secondary forests are assumed to be zero and $\mathrm{N}$ deposition is applied (Table 1). By subtracting S3 from S1, the contribution of secondary forest to terrestrial $\mathrm{C}$ uptake when $\mathrm{N}$ deposition is included is determined (Fig. 4).

Our model results suggest that on a global scale secondary forests have acted as a $\mathrm{C}$ sink for atmospheric $\left[\mathrm{CO}_{2}\right]$ continually from 1900 to 2000. During the 1990s, the total C sink associated with the secondary forests is $0.36 \mathrm{GtC} / \mathrm{yr}$ (Fig. 4). These results suggest that without considering the secondary forest regrowth, the net land use emissions in the 1990s could have been $1.58 \mathrm{GtC} / \mathrm{yr}$ or about $30 \%$ higher.

Figure 5 shows that secondary forests act as a $\mathrm{C}$ sink, especially in Northern Hemisphere. This is consistent with previous studies (Pacala et al., 2002; Hurtt et al., 2002; SOCCR, 2007), which indicate a significant Northern Hemisphere sink based on land measurement. Shevliakova et al. (2009) using SAGE/HYDE land use change data from Hurtt (2006) and shifting cultivation estimate the $\mathrm{C}$ sink associated with secondary forests of $0.35 \mathrm{GtC} / \mathrm{yr}$, which is consistent with the ISAM estimated value. However, the $\mathrm{C}$ sink estimated by Shevliakova et al. (2009) is almost entirely in the Southern Hemisphere, whereas our modeled sink is mainly in the Northern Hemisphere (Fig. 5). The differences could be attributed to the model assumptions and environmental factors. 


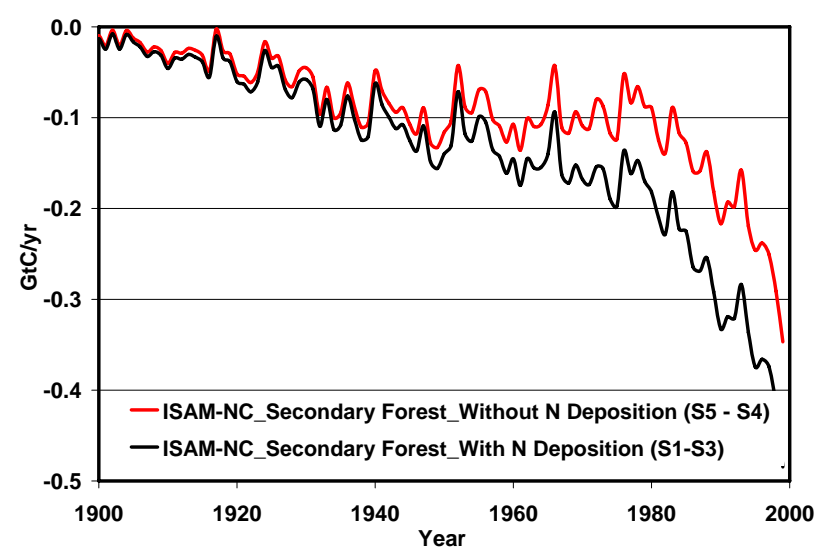

Fig. 4. Global net carbon flux ( $\mathrm{GtC} / \mathrm{a})$ in secondary forests comparing ISAM-NC including $\mathrm{N}$ deposition (S1 minus S3) and ISAMNC-without N deposition (S5 minus S4) between 1900 and 2000. Positive values represent net $\mathrm{C}$ release to the atmosphere and negative values represent net $\mathrm{C}$ storage in terrestrial biosphere.

While Shevliakova et al. (2009) uses a terrestrial C only model, we use a terrestrial carbon-nitrogen cycle model so account for carbon-nitrogen dynamics feedbacks. Shevliakova et al. (2009) did not consider the impacts of several environmental factors such as atmospheric $\left[\mathrm{CO}_{2}\right]$, climate, and $\mathrm{N}$ deposition, which are included in this study.

The magnitude of sink due to secondary forests, however, is affected by $\mathrm{N}$ deposition (Fig. 4), which is estimated by subtracting $\mathrm{C}$ fluxes estimate based on experiment $\mathrm{S} 4$ from that of S5. Increasing secondary forests area over the period 1900-2000 drives terrestrial ecosystems to act as a sink for with and without $\mathrm{N}$ deposition cases (Fig. 4). The $\mathrm{C}$ uptake rates however, are lower for without $\mathrm{N}$ deposition cases than for with $\mathrm{N}$ deposition case between 1900 and 2000 as shown in Fig. 4. The ISAM estimated contribution of $\mathrm{N}$ deposition to the $\mathrm{C}$ uptake associated with secondary forests is about $0.13 \mathrm{GtC} / \mathrm{yr}$ in $1990 \mathrm{~s}$ that is about $36 \%$ of the total secondary forest carbon sink.

Our estimate of additional terrestrial $\mathrm{C}$ uptake due to $\mathrm{N}$ deposition on all ecosystem types globally is $0.31 \mathrm{GtC} / \mathrm{yr}$, which suggests that $\mathrm{C}$ uptake in secondary forests due to $\mathrm{N}$ deposition constitutes about $42 \%$ of the total addition $\mathrm{C}$ uptake induced by $\mathrm{N}$ deposition. The impact of $\mathrm{N}$ deposition is most pronounced in temperate regions of Northern Hemisphere (Fig. 5), where most of the secondary forest area is increasing with time and nitrogen deposition level is relatively high. While our estimate of global $\mathrm{N}$ deposition induced $\mathrm{C}$ uptake is comparable to estimates based on ${ }^{15} \mathrm{~N}$ tracer field experiments $(0.25 \mathrm{GtC} / \mathrm{yr}$, Nadelhoffer et al., 1999) and results from other process-based models such as Thornton et al. ( 2007) $(0.24 \mathrm{GtC} / \mathrm{yr})$ and Zaehle et al. (2010) $(0.2 \mathrm{GtC} / \mathrm{yr})$; they are much lower than Churkina et al. (2007) estimates, which suggest that land ecosystems could take up additional $0.75-2.21 \mathrm{GtC} / \mathrm{yr}$ in 1990 s because of $\mathrm{N}$ deposi-

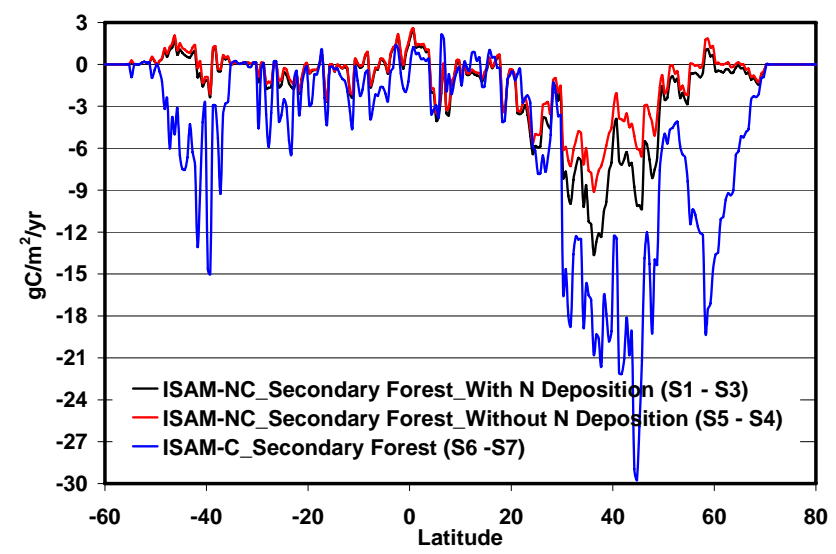

Fig. 5. Latitudinal distribution of net carbon flux ( $\mathrm{gC} / \mathrm{m} 2 / \mathrm{yr})$ for the 1990s in secondary forests for ISAM-NC with N deposition (S1 minus S3), ISAM-NC without $\mathrm{N}$ deposition (S5 minus S4) and ISAM$\mathrm{C}$ (S6 minus $\mathrm{S} 7$ ). In ISAM-NC experiments, $\mathrm{C}$ fluxes are affected by $\mathrm{N}$ dynamics, whereas in ISAM-C experiment $\mathrm{C}$ fluxes are not affected by $\mathrm{N}$ dynamics. Positive values represent net $\mathrm{C}$ release to the atmosphere and negative values represent net $\mathrm{C}$ storage in terrestrial biosphere.

tion. While the exact cause of this discrepancy is unclear, a few factors can be identified which may have contributed the difference in estimates. The discrepancy could be related to the fact Churkina et al. (2007) did not consider land use changes and assume land cover remains constant during 1980-1999 while in this study land cover changes are driven by historical land use change data including substantial forest regrowth. Additional reason could be the difference in the treatment of $\mathrm{N}$ cycle processes and carbon-nitrogen interactions in Churkina et al. (2007) and this study. For example, in the BIOME-BGC model used in Churkina et al. (2007), denitrification loss of $\mathrm{N}$ is assumed a fixed proportion of $\mathrm{N}$ mineralization. While in ISAM-NC, denitrification loss of $\mathrm{N}$ is a function of available nitrate $\mathrm{N}$, soil moisture, and heterotrophic respiration (Yang et al., 2009).

It is worth mentioning that in some areas that receive excessive amounts of $\mathrm{N}$ deposition from the atmosphere, $\mathrm{N}$ saturation may happen. An overabundance of available $\mathrm{N}$ may lead to undesired ecosystem effects including greater losses of nitrate to receiving waters, increased soil acidity, increased aluminum mobility and ultimately the decline of forest productivity (Aber et al., 1998). However we have not accounted for this adverse effect of $\mathrm{N}$ deposition in this study.

\subsection{Impact of nitrogen dynamics on carbon fluxes in secondary Forests}

To estimate the $\mathrm{C}$ fluxes in secondary forests when $\mathrm{N}$ dynamics are excluded from carbon cycle processes, two experiments with ISAM-C model version are performed, i.e. S6 and S7. In S7 C fluxes in secondary forests are assumed zero, whereas in experiment S6 C fluxes are calculated with 


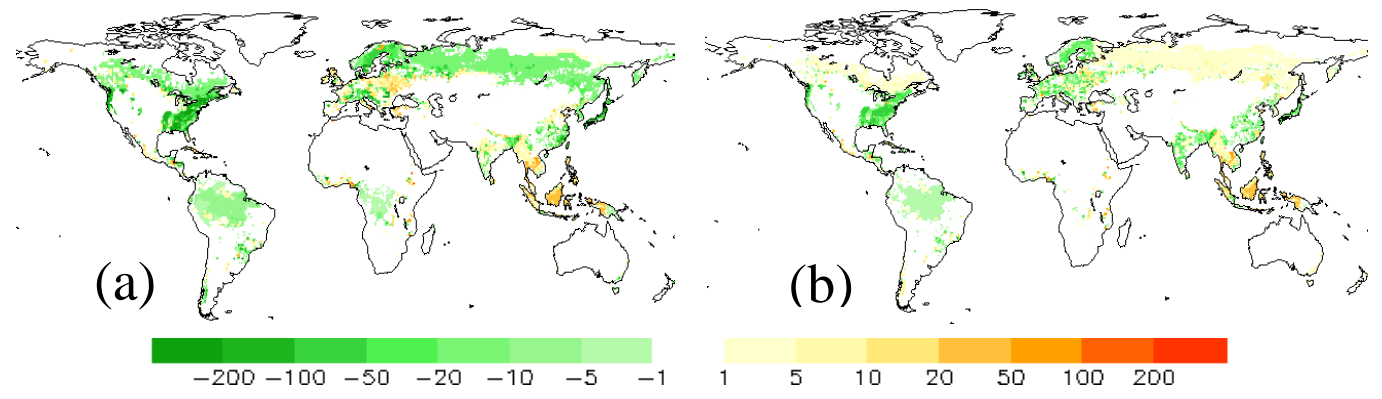

Fig. 6. Spatial distributions of the net exchange of carbon $\left(\mathrm{gC} / \mathrm{m}^{2} / \mathrm{yr}\right)$ for the $1990 \mathrm{~s}$ in secondary forests for (a) ISAM-C and (b) ISAMNC. C fluxes estimated based on ISAM-C version of the model are not constrained by $\mathrm{N}$ dynamics, whereas ISAM-NC based C fluxes are constrained by the $\mathrm{N}$ dynamics. Positive values represent net $\mathrm{C}$ release to the atmosphere and negative values represent net $\mathrm{C}$ storage in terrestrial biosphere

accounting the effect of secondary forests (Table 1). We then determine the contribution of secondary forests without $\mathrm{N}$ dynamics to terrestrial $\mathrm{C}$ uptake by subtracting $\mathrm{S} 7$ from S6. By comparing secondary forest contribution to $\mathrm{C}$ uptake based on ISAM-NC ( $\mathrm{S} 3$ minus $\mathrm{S} 1$ as discussed in Sect. 3.2) and that based on ISAM-C, we determine the impact of $\mathrm{N}$ dynamics on the secondary forest $\mathrm{C}$ fluxes.

Our model results show that secondary forests could act as either source or sink of $\mathrm{C}$, depending on the balance between $\mathrm{C}$ uptake by regrowing forests and $\mathrm{C}$ release from litter and soils (Fig. 6). In general there is less $\mathrm{C}$ uptake associated with secondary forests when $\mathrm{N}$ dynamics are considered (Fig. 6b) as compared to the case when $\mathrm{N}$ dynamics are not considered (Fig. 6a). A decrease in the $\mathrm{C}$ sink is more pronounced in Eastern United States, southern Canada, northern Europe and Russia's secondary forests (Fig. 6b). When the impacts of $\mathrm{N}$ dynamics on $\mathrm{C}$ fluxes are considered, $\mathrm{N}$ becomes a limiting nutrient in most regions where forest is regrowing, because large amount of $\mathrm{N}$ in soils was lost due to LUC history. Furthermore, although increasing atmospheric $\left[\mathrm{CO}_{2}\right]$ could lead to an increased $\mathrm{C}$ uptake in secondary forests, the enhanced $\mathrm{C}$ uptake is lowered when $\mathrm{N}$ dynamics are considered. This is because the $\mathrm{N}$ demand by trees under high $\left[\mathrm{CO}_{2}\right]$ is higher in order to support new production. This leads to further $\mathrm{N}$ limitation in secondary forests.

However, southern Europe as well as Indian secondary forests are sequestering more $\mathrm{C}$ when $\mathrm{N}$ dynamics are considered. Possible reasons are: (1) when natural vegetation was cleared for cropland, pastureland, or wood harvest, both above- and below-ground litter increases because of the unburned slash and the buried roots. The increased litter associated with LUC would lead to more litter decomposition and $\mathrm{N}$ mineralization, therefore increasing $\mathrm{N}$ availability in soil; (2) ash additions resulted from burned slash immediately increases inorganic $\mathrm{N}$ supply; (3) the warm and moist climate in India leads to the rapid decomposition of soil organic matter, which releases mineral $\mathrm{N}$ due to nitrogen min- eralization. These released mineral $\mathrm{N}$ is taken by the plants for the regrowth of secondary forests, thus enhancing secondary forest carbon sink; (4) the temperature and precipitation conditions in India region favors biological nitrogen fixation, which provides substantial amount of nitrogen for India secondary forests and enhance their productivity; (5) nitrogen deposition effect in southern Europe is enhancing the productivity of secondary forests in this region.

Although it has been suggested that phosphorus and not $\mathrm{N}$ limits productivity in tropical forests (Vitousek and Howarth, 1991), a recent meta-analysis (Lebauer et al., 2000) and several field studies (Davidson et al., 2004; Murty et al., 2002, Herbert et al., 2003) report strong $\mathrm{N}$ limitation in the secondary forests of tropical regions. Our model results clearly show that $\mathrm{N}$ is a limiting nutrient in tropical secondary forests in Latin America and Tropical Africa (Fig. 6). Although primary tropical forest is usually not $\mathrm{N}$ limiting, LUC, especially wood harvest, removes large amount of $\mathrm{N}$ from the system during the processes of burning of remaining slash and harvesting of wood. Without large amount of $\mathrm{N}$ input, regrowth of tropical secondary forest would usually be $\mathrm{N}$ limited. Nevertheless, our model results in the Indian region show that $\mathrm{C}$ uptake is enhanced due to the introduction of $\mathrm{N}$ dynamics, probably due to enhanced $\mathrm{N}$ mineralization and increased $\mathrm{N}$ availability as we discussed in last paragraph. These results suggest that the $\mathrm{N}$ cycling effect in tropical regions is spatially heterogeneous depending on geographic location.

As shown in Fig. 5, secondary forests act as a substantial $\mathrm{C}$ sink, especially those in Northern Hemisphere. The magnitude of the secondary forest sink is highly dependent on the $\mathrm{N}$ availability in secondary forests. In general, $\mathrm{C}$ uptake by regrowing forests is limited by $\mathrm{N}$ availability, especially in temperate regions where $\mathrm{N}$ is a primary limiting nutrient (Figs. 5 and 6). Without accounting for $\mathrm{N}$ dynamics, the estimates of secondary forest sink in 1990s is $0.90 \mathrm{GtC} / \mathrm{yr}$, about $0.54 \mathrm{GtC} / \mathrm{yr}$ (or $150 \%$ ) higher than with 
$\mathrm{N}$ dynamics case. Houghton (2003) estimated C sink associated secondary forests is about $1.18 \mathrm{GtC} / \mathrm{yr}$. This estimate would be reduced greatly if $\mathrm{N}$ limitation on forest regrowth were included.

\section{Discussion and conclusions}

In this paper we have investigated the impact of secondary forest on global land use emission and how interactions between historical LUC, $\mathrm{C}$ cycle and $\mathrm{N}$ cycle affect terrestrial $\mathrm{C}$ fluxes in secondary forests on the global scale. This study extends our previous analyses of the global land use $\mathrm{C}$ fluxes (Jain and Yang, 2005) and of the impacts of $\mathrm{N}$ dynamics on terrestrial C fluxes (Jain et al., 2009) by applying a fully coupled carbon-nitrogen cycle model and a comprehensive LUC history that account for changes of cropland, pastureland, and wood harvest.

Results of this study suggest that global land use emissions associated with changes in cropland, pastureland, and wood harvest reached peak in 1950s, and starting from around 1960 there is a sharp decrease of land use emissions until 1990. The effects of LUC is spatially heterogeneous, with most regions showing $\mathrm{C}$ emissions while some regions such as eastern United States, Europe, and Austrian showing C sinks due to LUC. The estimate of global land use emissions for the $1990 \mathrm{~s}$ is $1.22 \mathrm{GtC} / \mathrm{yr}$, which is well within the range of values estimated by IPCC AR4 (0.5-2.7 GtC/yr) (Denman et al., 2007). Our model results also suggest that without considering the secondary forest regrowth, the net land use emissions in the $1990 \mathrm{~s}$ are $1.58 \mathrm{GtC} / \mathrm{yr}$ or about $0.36 \mathrm{GtC} / \mathrm{yr}$ higher than without secondary forest regrowth case.

Our results show that secondary forests are a substantial sink of $\mathrm{C}$ globally $(0.36 \mathrm{GtC} / \mathrm{yr}$ in the $1990 \mathrm{~s})$. This is more than $150 \%$ lower than that given by Houghton et al. (2003), mostly because $\mathrm{N}$ limitation was considered in this study. Our study also demonstrates that there is a significant Northern Hemisphere sink, where most of lands use changes and forest regrowth happens. This is consistent with previous studies based on land-measurement (Goodale et al., 2002; Hurtt et al., 2002; Pacala et al., 2001; SOCCR, 2007). Our study also shows the significant contribution of $\mathrm{N}$ deposition to the secondary forest sink. $\mathrm{N}$ deposition is responsible for about $36 \%$ of the total secondary forest sink (about $0.13 \mathrm{GtC} / \mathrm{yr}$ in 1990s).

This study highlights the importance of $\mathrm{N}$ dynamics to the secondary forest sinks on the global scale. These calculations suggest that the introduction of $\mathrm{N}$ dynamics leads to the reduction of secondary forest $\mathrm{C}$ sinks, especially in temperate regions. The possible reasons are: (1) $\mathrm{N}$ is a limiting nutrient in these regions; (2) LUC history leads to a loss of $\mathrm{N}$ from soil; (3) the increasing $\left[\mathrm{CO}_{2}\right]$ and resulted $\mathrm{CO}_{2}$ fertilization effect on regrowing forests leads to an additional demand for $\mathrm{N}$. Our model results also indicate the $\mathrm{N}$ limitation in tropical secondary forests, which is consistent with field experiments but has not considered in most previous modeling studies.
On the other hand, in some regions such as India our study shows that the growth of secondary forests was enhanced due to the introduction of $\mathrm{N}$ dynamics, the reason is being that enhanced litter decomposition and thus $\mathrm{N}$ mineralization resulting from LUC leads to additional mineral nitrogen, which could increase tree productivity.

Our results presented here are subject to uncertainties related to uncertainty in the data used, incomplete representation and/or simplifying assumptions of processes in the model. First, we believe there is a large uncertainty in the land use change data used in this study. Since global spatial historical land use change data is not available directly, land use change data used in this study was reconstructed based on earlier land use history reconstruction for agricultural land (Ramankutty and Foley, 1999; Klein Gokdewijk, 2001), and wood harvest in spatial detail based on several assumptions (Hurtt et al., 2006). In our previous study (Jain and Yang, 2005) we estimated the uncertainties in the land use emissions and net land-atmosphere $\mathrm{CO}_{2}$ fluxes using two different land cover data sets for croplands (Ramankutty and Foley, 1999; Houghton and Hackler, 2001), each was combined with one single set of pastureland data (Klein Goldewijk, 2001). We concluded that differences between the two sets of land use fluxes are primarily due to the differences in the rates of changes in land area amount for croplands and argued that further investigation in data for croplands with ground and satellite-based measurements is needed. The introduction of wood harvest (Hurtt et al., 2006) in this study might have further amplified the uncertainty range associated with land use change data. In the case of secondary forests, this study assumes that secondary forests are naturally developed through reforestation and forest regrowth on abandoned land. However, in some parts of the world, for example in Japan and South East Asia, secondary forests are not naturally developed, but are planted (Kenda, 2000; Merker et al., 2004). So, this study may be underestimating the secondary forest area. Another potential area of uncertainty is that the representation of certain processes, such as fire suppression and woody encroachment, which are suggested to contribute greatly to regional carbon sink (Pacala et al., 2002), are not included in this study, because the effects of these processes have not been well defined yet due to lack of comprehensive data (Denman et al., 2007). Moreover, shifting cultivation activity is not included in this study because neither the area in shifting cultivation nor the carbon dynamics related to this process is well understood. This could lead to the underestimation of both the land use emissions and secondary carbon sink. Lastly, we assume that plants only take up mineral nitrogen in soils. We are not considering the pathway for nitrogen uptake through the stomata of leaves, which has been suggested as an important pathway for forest to assimilate deposited nitrogen (Jenkinson 1999; Sievering 1999; Sievering et al., 2000). This may cause the underestimation of carbon sink due to secondary forest, especially in regions where nitrogen deposition level is high. 
Overall, this study indicates the significant contribution of secondary forests to the terrestrial $\mathrm{C}$ sinks over the historical time, the importance of nitrogen dynamics in estimating the secondary forests carbon sinks, and therefore the need to include both primary and secondary forests and nitrogen cycle dynamics in global terrestrial ecosystem models.

Acknowledgements. We acknowledge Victoria Wittig whose comments lead to improvements in this manuscript. We thank F. Dentener for providing us the $\mathrm{N}$ deposition data. We also acknowledge the financial support of the National Aeronautics and Space Administration Land Cover and Land Use Change Program (NNX08AK75G).

Edited by: N. Ohte

\section{References}

Aber, J., McDowell, W., Nadelhoffer, K., Magill, A., Berntson, G., Kamakea, M., McNulty, S., Currie, W., Rustad, L., and Fernandez, I.: Nitrogen saturation in temperate forest ecosystems, Bioscience, 48, 921-934, 1998.

Canadell, J. G., Pataki, D. E., Gifford, R., Houghton, R. A., Luo, Y., Raupach, M. R., Smith, P., and Steffen, W.: Saturation of the terrestrial carbon sink, Terrestrial Ecosystems in a Changing World, edited by: Canadell, J. G., Pataki, D. E., and Pitelka, L. F., Berlin Heidelberg, Springer-Verlag, 2007.

Caspersen, J. P., Pacala, S. W., Jenkins, J. C., Hurtt, G. C., Moorcroft, P. R., and Birdsey, R. A.: Contributions of land-use history to carbon accumulation in US forests, Science, 290(5494), 11481151, 2000.

Churkina, G., Trusilova, K., Vetter, M., and Dentener, F.: Contributions of nitrogen deposition and forest regrowth to terrestrial carbon uptake, Carbon Balance and Management, 2, 5, doi:10.1186/1750-0680-2-5, 2007.

Cleveland, C. C., Townsend, A. R., Schimel, D. S., Fisher, H., Howarth, R. W., Hedin, L. O., Perakis, S. S., Latty, E. F., Von Fischer, J. C., and Elseroad, A.: Global patterns of terrestrial biological nitrogen $\left(\mathrm{N}_{2}\right)$ fixation in natural ecosystems, Global Biogeochem. Cy., 13(2), 623-645, doi:10.1029/1999GB900014, 1999.

Davidson, E. A., Reis de Carvalho, C. J., Vieira, I. C. G., Figueiredo, R. O., Moutinho, P., Yoko Ishida, F., Primo dos Santos, M. T., Benito Guerrero, J., Kalif, K., and Tuma Sabá, R.: Nitrogen and phosphorus limitation of biomass growth in a tropical secondary forest, Ecol. Appl., 14(4), 150-163, 2004.

Denman, K. L.: Coupling between changes in the climate system and biogeochemistry, in: Climate Change 2007: The Physical Science Basis. Contribution of Working Group I to the Fourth Assessment Report of the International Panel on Climate Change, edited by: Solomon, S., et al., 499-587, Cambridge Univ. Press, Cambridge, U. K., 2007.

FAOSTAT: Statistical Database of the United Nations Food and Agricultural Organization, available on: http://apps.fao.org/, visited Feb. 2004.

Friedli, H., Lötscher, H., Oeschger, H., Siegenthaler, U., and Stauffer, B.: Ice core record of ${ }^{13} \mathrm{C} /{ }^{12} \mathrm{C}$ ratio of atmospheric $\mathrm{CO}_{2}$ in the past two centuries, Nature, 324, 237-238, 1986.
Galloway, J., Dentener, F., Capone, D., Boyer, E., Howarth, R., Seitzinger, S., Asner, G., Cleveland, C., Green, P., and Holland, E.: Nitrogen cycles: past, present, and future, Biogeochemistry, 70(2), 153-226, 2004.

Goodale, C. L., Apps, M. J., Birdsey, R. A., Field, C. B., Heath, L. S., Houghton, R. A., Jenkins, J. C., Kohlmaier, G. H., Kurz, W., and Liu, S.: Forest carbon sinks in the northern hemisphere, Ecol. Appl., 12(3), 891-899, 2002.

Guariguata, M. R. and Ostertag, R.: Neotropical secondary forest succession: changes in structural and functional characteristics, For. Ecol. Manage., 148(1-3), 185-206, 2001.

Herbert, D. A., Williams, M., and Rastetter, E. B.: A model analysis of $\mathrm{N}$ and $\mathrm{P}$ limitation on carbon accumulation in Amazonian secondary forest after alternate land-use abandonment, Biogeochemistry, 65(1), 121-150, 2003.

Holland, E. A., Braswell, B., Lamarque, J. F., Townsend, A., Sulzman, J., Müller, J. F., Dentener, F., Brasseur, G., Levy II, H., and Penner, J. E.: Variations in the predicted spatial distribution of atmospheric nitrogen deposition and their impact on carbon uptake by terrestrial ecosystems, J. Geophys. Res.-Atmos., 102(D13), 15849-15866, 1997.

Horn, H.: The ecology of secondary succession, Annu. Rev. Ecol. Syst., 5(1), 25-37, 1974.

Houghton, R.: Revised estimates of the annual net flux of carbon to the atmosphere from changes in land use and land management 1850-2000, Tellus, 55(2), 378-390, 2003.

Houghton, R.: Aboveground forest biomass and the global carbon balance, Global Change Biol., 11(6), 945-958, 2005.

Houghton, R., Hackler, J., and Lawrence, K.: The US carbon budget, contributions from land-use change, Science, 285(5427), 574-578, 1999.

Hurtt, G., Frolking, S., Fearon, M., Moore, B., Shevliakova, E., Malyshev, S., Pacala, S., and Houghton, R.: The underpinnings of land-use history: three centuries of global gridded land-use transitions, wood-harvest activity, and resulting secondary lands, Global Change Biol., 12(7), 1208-1229, 2006.

Hurtt, G., Pacala, S., Moorcroft, P., Caspersen, J., Shevliakova, E., Houghton, R., and Moore, B.: Projecting the future of the US carbon sink, Proceedings of the National Academy of Sciences, 99(3), 1389-1394, 2002.

Jain, A., Yang, X., Kheshgi, H., McGuire, A. D., Post, W., and Kicklighter, D. : Nitrogen attenuation of terrestrial carbon cycle response to global environmental factors, Global Biogeochem. Cy., 23, GB4028, doi:10.1029/2009GB003519, 2009.

Jain, A. K. and Yang, X.: Modeling the Effects of Two Different Land Cover Change Data Sets on the Carbon Stocks of Plants and Soils in Concert With $\mathrm{CO}_{2}$ and Climate Change, Global Biogeochem. Cy., 19, GB2015, doi:10.1029/2004GB002349, 2005.

Jenkinson, D. S., Goulding, K., and Powlson, D. S.: Nitrogen deposition and carbon sequestration, Nature, 400, 629-630, 1999.

Keeling, C. D., Bacastow, R. B., and Whorf, T. P.: Measurements of the concentration of carbon dioxide at Mauna Loa Observatory, Hawaii, in: Carbon Dioxide Review, edited by: Clark, W. C., 377-385, Oxford Univ. Press, New York, 1982.

Keeling, C. D. and Whorf, T. P.: Atmospheric $\mathrm{CO}_{2}$ records from sites in the SIO air sampling network. In Trends: A Compendium of Data on Global Change. Carbon Dioxide Information Analysis Center, Oak Ridge National Laboratory, U.S. Department of Energy, Oak Ridge, Tenn., U.S.A, 2007. 
Kenda, K.: Recycling of Forests: Overseas Forest Plantation Projects of Oji Paper Co., Ltd., Japan TAPPI Journal, 54(1), 4548, 2000.

Klein Goldewijk, K.: Estimating global land use change over the past 300 years: the HYDE database, Global Biogeochem. Cy., 15(2), 417-433, 2001.

LeBauer, D. S. and K. K. Treseder: Nitrogen limitation of net primary productivity in terrestrial ecosystems is globally distributed, Ecology, 89(2), 371-379, 2008.

Lelieveld, J. and Dentener, F. J.: What controls tropospheric ozone? J. Geophys. Res.-Atmos., 105(D3), 3531-3551, 2000.

Mathers, N. J., Harms, B., and Dalal, R. C.: Impacts of land-use change on nitrogen status and mineralization in the Mulga Lands of Southern Queensland, Austral Ecol., 31(6), 708-718, 2006.

Merker, S., Yustian, I., and Muhlenberg, M.: Losing Ground but Still Doing Well-Tarsius dianae in Human-Altered Rainforests of Central Sulawesi, Indonesia, edited by: Gerold, G., Fremerey, M., and Guhardja, E., Land Use, Nature Conservation and the Stability of Rainforest margins in Southeast Asia, Springer, 299311, 2004.

Mitchell, T. D. and Jones, P. D.: An improved method of constructing a database of monthly climate observations and associated high-resolution grids, Int. J. Climatol., 25(6), 693-712, 2005.,

Murty, D., Kirschbaum, M. U. F., Mcmurtrie, R. E., and Mcgilvray, H.: Does conversion of forest to agricultural land change soil carbon and nitrogen? A review of the literature, Global Change Biol., 8(2), 105-123, 2002.

Nadelhoffer, K. J., Emmett, B. A., Gundersen, P., Kjonaas, O., Koopmans, C. J., Schleppi, P., Tietema, A., and Wright, R. F.: Nitrogen deposition makes a minor contribution to carbon sequestration in temperate forests, Nature, 398(6723), 145-148, 1999.

Neftel, A., Moor, E., Oeschger, H., and Stauffer, B.: Evidence from polar ice cores for the increase in atmospheric $\mathrm{CO}_{2}$ in the past two centuries, Nature, 315, 45-47, 1985.

Pacala, S., Hurtt, G., Baker, D., Peylin, P., Houghton, R., Birdsey, R., Heath, L., Sundquist, E., Stallard, R., and Ciais, P.: Consistent land-and atmosphere-based US carbon sink estimates, Science, 292(5525), 2316-2320, 2001.

Pimentel, D. and Kounang, N.: Ecology of soil erosion in ecosystems, Ecosystems, 1(5), 416-426, 1998.

Ramankutty, N. and Foley, J. A.: Estimating historical changes in global land cover: Croplands from 1700 to 1992, Global Biogeochem. Cy., 13(4), 997-1027, 1999.

Ramankutty, N., Gibbs, H. K., Achard, F., DeFries, R., Foley, J. A., and Houghton, R.: Challenges to estimating carbon emissions from tropical deforestation, Global Change Biol., 13(1), 51-66, 2007.

Reay, D. S., Dentener, F., Smith, P., Grace, J., and Feely, R. A.: Feely Global nitrogen deposition and carbon sinks, Nat. Geosci., 1, 430-437, 2008.

Schimel, D. S., Braswell, B., McKeown, R., Ojima, D., Parton, W., and Pulliam, W.: Climate and nitrogen controls on the geography and timescales of terrestrial biogeochemical cycling, Global Biogeochem. Cy., 10, 677-692, doi:10.1029/96GB01524, 1996.
Schipper, L., Baisden, W., Parfitt, R., Ross, C., Claydon, J., and Arnold, G.: Large losses of soil $\mathrm{C}$ and $\mathrm{N}$ from soil profiles under pasture in New Zealand during the past 20 years, Global Change Biol., 13(6), 1138-1144, 2007.

Shevliakova, E., Pacala, S. W., Malyshev, S., Hurtt, G. C., Milly, P., Caspersen, J. P., Sentman, L. T., Fisk, J. P., Wirth, C., and Crevoisier, C.: Carbon cycling under 300 years of land use change: Importance of the secondary vegetation sink, Global Biogeochem. Cy., 23(2), GB2022, doi:10.1029/2007GB003176, 2009.

Sievering, H.: Nitrogen deposition and carbon sequestration, Nature, 400, 629-630, 1999.

Sievering, H., Fernandez, I., Lee, J., Hom, J., and Rustad, L.: Forest canopy uptake of atmospheric nitrogen deposition at eastern U.S. conifer sites: Carbon storage implications?, Global Biogeochem. Cy., 14(4), 1153-1159, doi:10.1029/2000GB001250, 2000.

Smil, V.: Enriching the earth, MIT Press Cambridge, MA., 2001.

SOCCR: The First State of the Carbon Cycle Report (SOCCR): The North American Carbon Budget and Implications for the Global Carbon Cycle. A Report by the U.S., Climate Change Science Program and the Subcommittee on Global Change Research, edited by: King, A. W., et al., 242, NOAA, NCDC, Asheville, N. C., 2007.

Tanner, E. V. J., Vitousek, P. M., and Cuevas, E.: Experimental investigation of nutrient limitation of forest growth on wet tropical mountains, Ecology, 79, 10-22, 1998.

Thornton, P. E., Lamarque, J. F., Rosenbloom, N. A., and Mahowald, N. M.: Influence of carbon-nitrogen cycle coupling on land model response to $\mathrm{CO}_{2}$ fertilization and climate variability, Global Biogeochem. Cy., 21(4), doi:10.1029/2006GB002868, 2007.

Townsend, A., Braswell, B., Holland, E., and Penner, J.: Spatial and temporal patterns in terrestrial carbon storage due to deposition of fossil fuel nitrogen, Ecol. Appl., 6(3), 806-814, 1996.

Van Minnen, J. G., Klein Goldewijk, K., Stehfest, E., Eickhout, B., van Drecht, G., and Leemans, R.: The importance of three centuries of land-use change for the global and regional terrestrial carbon cycle, Climatic Change, 97(1-2), 123-144, 2009.

Vitousek, P. M. and Howarth, R. W.: Nitrogen limitation on land and in the sea: how can it occur? Biogeochemistry, 13(2), 87$115,1991$.

Woodbury, P. B., Heath, L. S., and Smith, J. E.: Land use change effects on forest carbon cycling throughout the southern United States, J. Environ. Qual., 35(4), 1348-1363, 2006.

Yang, X., Wittig, V. E., Jain, A. K., and Post, W.: Integration of nitrogen dynamics into a global terrestrial ecosystem model, Global Biogeochem. Cy., 23, GB4029, doi:10.1029/2009GB003474, 2009.

Zaehle, S., Friend, A. D., Friedlingstein, P., Dentener, F., Peylin, P., and Schulz, M.: Carbon and nitrogen cycle dynamics in the OCN land surface model: 2. Role of the nitrogen cycle in the historical terrestrial carbon balance, Global Biogeochem. Cy., 24, GB1006, doi:10.1029/2009GB003522, 2010. 